\title{
Evaluation of Serum Cystatin C Levels in Fibroid Patients in Elele
}

\author{
Nnatuanya IN ${ }^{1}$, Obeagu EI2*, Obeagu GU ${ }^{3}$, Nnatuanya $\mathrm{CIC}^{1}$ and Chukwudi EO ${ }^{1}$ \\ ${ }^{1}$ Department of Medical Laboratory Science, Madonna University, Elele, Rivers State, Nigeria \\ ${ }^{2}$ Diagnostic Laboratory Unit, Department of University Health Services, Michael Okpara University of Agriculture, Umudike, Abia State, Nigeria \\ ${ }^{3}$ Department of Nursing, Ebonyi State University, Abaliki, Nigeria
}

${ }^{*}$ Corresponding author: Emmanuel Ifeanyi Obeagu, Diagnostic Laboratory Unit, Department of University Health Services, Michael Okpara University of Agriculture, Umudike, Abia State, Nigeria, Tel: +2348037369912; E-mail: emmanuelobeagu@yahoo.com

Received date: July 04, 2017; Accepted date: September 26, 2017; Published date: September 29, 2017

Citation: Nnatuanya IN, Obeagu El, Obeagu GU, Nnatuanya CIC, Chukwudi EO (2017) Evaluation of serum Cystatin C levels in fibroid patients in Elele. Arch Med Vol No:9 Iss No:5:3

Copyright: (c) 2017 Nnatuanya IN, et al. This is an open-access article distributed under the terms of the Creative Commons Attribution License, which permits unrestricted use, distribution, and reproduction in any medium, provided the original author and source are credited.

\section{Abstract \\ This study was aimed at determining the serum levels of Cystatin C in fibroid patients. A total of 140 women were recruited for the study, 70 served as control while 70 were fibroid patients (test). Nephelometric Immunoassay Method in Mispa autoanlyser was used for the assay. The data were analyzed with statistical package for social science (SPSS) version 20. The results showed significant difference $(P<0.05)$ when Cystatin $C$ in fibroid subjects $(2.6 \pm 1.11$ $\mathrm{mg} / \mathrm{dl})$ were compared to control $(1.0 \pm 0.34 \mathrm{mg} / \mathrm{dl})$ and there was significant difference $(P<0.05)$ when Cystatin $C$ levels were compared among the different age groups. It was concluded that Cystatin $\mathrm{C}$ was elevated in fibroid women.}

\section{Keywords: Cystatin C; Fibroid patients; Elele}

\section{Introduction}

Fibroids are noncancerous growths of the smooth muscle layer of the uterus. Fibroids can range in number and size from a single growth to multiple growths $[1,2]$. The prevalence of fibroid varies between 5-65\% depending on age, ethnicity, geographical region and quality of imaging techniques [3-5]. Some fibroids may interfere with pregnancy although this appears to be uncommon [6]. Both genetic factors such as mutations and environmental factors such as obesity have been implicated in the development of fibroids [6].

\section{Materials and Methods}

\section{Study area}

The research was carried out on samples from women with fibroid attending Madonna University Teaching Hospital (MUTH) Elele, Rivers State, Nigeria.

\section{Study population}

A total of 140 women were enrolled for the study, 70 were fibroid patients (test) and 70 were apparently healthy women (control) attending Madonna University Teaching Hospital (MUTH) Elele.

\section{Ethical clearance}

Ethical clearance was obtained from the ethics Committee of Madonna University Elele, through the Head of Departemnt, Medical Laboratory Science which was approved by the management of Madonna University Teaching Hospital Elele.

\section{Informed consent}

Informed consent was obtained from the subjects before sample collection.

\section{Sample collection}

A $3 \mathrm{ml}$ of venous blood sample was collected from the subjects into plain tubes, allowed to clot and retract and the serum separated for the Cystatin $\mathrm{C}$ assay.

\section{Determination of Cystatin C by nephelometric immunoassay method}

\section{Procedure}

The assay was done with auto analyzer. The smart card was inserted, $100 \mu \mathrm{l}$ of R1 and $10 \mu \mathrm{l}$ of sample added into the cuvette placed in cuvette holder, mixed automatically for 10 seconds and incubated for 30 seconds. After, $140 \mu$ l of R2 was added into the cuvette and mixed for 10 seconds and then the result was displayed and read.

\section{Statistical analysis}

Data obtained from these studies were analysed using the statistical package of social science (SPSS) version 20. The results were expressed as mean \pm standard deviation (SD). Independent 
sample t-test was used to compare means and values considered significance at $P<0.05$. Analysis of variance (ANOVA) was used to compare means of the age groups.

\section{Results}

Table 1: Comparism between Cystatin C among fibroid and control subjects.

\begin{tabular}{|l|l|l|l|}
\hline Parameter & Control & Test & Level of significance \\
\hline Cystatin C (mg/dl) & $1.0 \pm 0.34$ & $2.6 \pm 1.11$ & $P<0.05$ \\
\hline
\end{tabular}

Table 2: Comparism of Cystatin $\mathrm{C}$ among fibroid and control subjects based on different age groups.

\begin{tabular}{|l|l|l|l|}
\hline Groups (years) & Control & Test & Level of significance \\
\hline $35-40$ & $0.92 \pm 0.30$ & $2.8 \pm 1.24$ & $\mathrm{P}<0.05$ \\
\hline $41-45$ & $1.1 \pm 0.37$ & $2.9 \pm 1.07$ & $\mathrm{P}<0.06$ \\
\hline $46-50$ & $1.1 \pm 0.31$ & $2.1 \pm 0.87$ & $\mathrm{P}<0.07$ \\
\hline
\end{tabular}

Table 3: Comparism of cystatin C among fibroid subjects based on different age Groups.

\begin{tabular}{|l|l|}
\hline Groups (years) & Cystatin C (mg/dl) \\
\hline $35-40$ & $2.8 \pm 1.24$ \\
\hline $41-45$ & $2.9 \pm 1.07$ \\
\hline $46-50$ & $2.1 \pm 0.87$ \\
\hline
\end{tabular}

\section{Discussion}

Cystatin C is a protein encoded by the CST3 gene. It is a known biomarker of kidney function. Cystatin $\mathrm{C}$ is found in virtually all tissues and body fluids. The mean value of serum cystain $C$ in fibroid subjects $(2.6 \pm 1.11 \mathrm{mg} / \mathrm{dl})$ showed significant increase $(P<0.05)$ compared to control $(1.0 \pm 0.34 \mathrm{mg} / \mathrm{dl})$. This can be due to the increase in cellular activity in the fibroid growth. According to Akbari [7], increased Cystatin C in late pregnancy and preeclampsia has been explained by changes in renal handling of the protein. There may be increased synthesis of Cystatin $C$ in fibroid patients $[8,9]$. The results of the different age groups of fibroid and control subjects showed significant difference $(P<0.05)$ when compared based on the age groups of the fibroid subjects. This shows that the age of the women is highly associated with the changes in the level of Cyctatin $C$ in the subjects [10].

\section{Conclusion}

It can be concluded that the serum levels of Cystatin $C$ is elevated in fibroid which could be due to increased cellular activity in the fibroid growth. This could be of diagnostic value in fibroid and in the management of the patients. It is crucial to monitor Cystatin $\mathrm{C}$ to find out the level of renal derangement in fibroid patients.

\section{References}

1. Baird DD, Dunson DB (2003) Why is parity protective for uterine fibroids? Epidemiology 14: 247-250.

2. Moorman PG, Leppert P, Myers ER, Wang F (2013) Comparism of characteristics of fibroid in african american and white women undergoing premenopausal hysterectomy. Fertil Steril 99: 768-776.

3. Baird DD, Hill MC, Schectman JM, Hollis BW (2013) Vitamin D and the risk of Uterine Fibroids. Epidemiology 24: 447-453.

4. Marsh EE, Ekpo GE, Cardozo ER, Brocks M, Dune T, et al. (2013) Racial differences in fibroid prevalence and ultarsound findings in asymptomatic young women (18-30 years): A pilot study. Fertil Steril 99:1951-1957.

5. Meyers SL, Baird DD, Oslam AF, Herring AH, Schroede JC, et al. (2012) Self-report versus ultrasound measurement of uterine fibroid status. J Womens Health 21: 285-293.

6. Neiger R, Sonek JD, Croom CS, Ventolin G (2006) Pregancy-related changes in the size of uterine leiomyomas. J Reprod Med 51: 671-674.

7. Akbari A (2004) Glomerular endotheliosis in normal pregnacy and preeclampsia. Br J Obstet Gynaecol 111: 193-195.

8. Stevens H, Wide-Swensson D, Grubb A (2001) Serum Cysytatin C is a better marker for pre-eclampsia than serum creatinine or serum urate. Scand J Clin Lab Invest 61: 575-580.

9. Cataldi L, Mussap M, Bertelli L, Ruzzante N, Fanos V, et al. (1999) Cystatin $C$ in healthy women at term pregnancy and in their infant newborns: relationship between maternal and neonatal serum levels and refernce values. Am J Perinatol 16: 287-295.

10. Bfkenkamp A, Dieterich C, Schumann G (1999) Pediatric reference values for Cysytatin C revisted. Pediatr Nephrol 13: 367-368. 